\title{
Development and displacement: the national involuntary resettlement policy (NIRP) in practice
}

\author{
N Godamunne \\ Centre for Poverty Analysis (CEPA), No. 29, Gregory's Road, Colombo 07
}

\begin{abstract}
Across the globe more than ten million people are displaced annually by programs which promotenational, regional and local development. Sri Lanka too has large infrastructure projects which cause displacement and resettlement. Given the government's vision to prioritize infrastructure development, Sri Lanka is likely to witness a growing number of people affected by development induced displacement and resettlement. The National Involuntary Resettlement Policy (NIRP) was formulated and came into effect through cabinet approval in 2000. The policy focuses on involuntary resettlement related to public and private sector development projects covering land acquisition and resettlement to ensure that people are not negatively affected and are able to restore their living standards and integrate into their new environments. This paper seeks to analyze the implementation of the NIRP with respect to recent development projects, notably; the Southern Transport Development Project, the Colombo Katunayake Expressway, the Outer Circular Highway and the Lunawe Environmental Improvement and Community Development projects. The paper draws on the Centre for Poverty Analysis own experience and information derived from secondary sources on; payment of monetary and non-monetary compensation, impact on living standards and livelihoods among households affected by the projects. It attempts to situate the empirical evidence gathered from the projects reviewed in the context of the principles of the NIRP in particular and within the broader impoverishment risks discourse in involuntary resettlement. The overarching objective of this paper is to interrogate the NIRP as a social protection measure implemented in a recent development project.
\end{abstract}

Keywords: Development induced displacement, resettlement, National Involuntary Resettlement Policy (NIRP)

\section{INTRODUCTION}

It is estimated that across the globe, ten million people are displaced annually by programmes which promote national, regional and local development (Cernea, 1997). Whilst China and India have some of the largest numbers of people affected by Development-Induced Displacement and Resettlement (DIDR) in Asia, the numbers in Sri Lanka are much smaller. However, recent development projects, particularly in the infrastructure sector, have displaced a considerable number of people. It is therefore, pertinent to investigate the social protection measures that are currently applicable to Affected Persons (APs) through development projects. This paper seeks to analyse the implementation of the National Involuntary Resettlement Policy (NIRP) in respect of recent development projects, mainly the Southern Transport Development Project (STDP), and also the Colombo Katunayake Expressway (CKE), the Lunawe Environmental Improvement and Community Development Project (LEICDP) and other smaller development projects involving significant displacement and resettlement.

The NIRP was formulated in 2000 and came into effect through Cabinet approval in 2001. The policy objective was to focus on involuntary resettlement related to public and private sector development projects covering both land acquisition and resettlement, to ensure that people are not negatively affected and are able to restore their standard of living and integrate into their new environment (NIRP, 2001). The Southern transport development project is the first large scale development project which adopted the principles of the NIRP. Due to the scale of the project and the availability of literature, the STDP is the main case study used in this paper. Analysis of data from the STDP has been possible through data collected by Centre for Poverty Analysis (CEPA) as the independent external monitor for resettlement in the STDP and the 
author's own fieldwork on a thesis for a Masters Degree. Whilst more recent development induced displacement and resettlement projects have also been referred to, due to a dearth of detailed information and in particular, the lack of independent data on monitoring resettlement activities, it has not been possible to analyse the data on these projects in detail.

As stated above, the objective of the NIRP is to ensure that people affected by development projects are not negatively impacted. This paper will analyse the implementation of the NIRP using the STDP as a case study focusing on three key principles of the NIRP in relation to economic and social aspects of displacement and resettlement. The paper begins with a brief conceptual framework of DIDR in a global context. Whilst there are different types of DIDR, this paper will focus on infrastructure development projects and discuss the theoretical framework of DIDR in terms of Micheal Cernea's Risk and Reconstruction Model (Cernea, 1997). The next section will provide a brief historical overview of development induced displacement and resettlement in Sri Lanka, focusing on earlier projects such as the Accelerated Mahaweli Development Programme (AMDP). The section that follows begins with a discussion on the concept of social protection and a working definition of the term in the context of the NIRP. It lays out the principles of the NIRP and continues with an analysis of its implementation in relation to recent development projects in Sri Lanka with particular reference to the Southern transport development project. The final section will provide an analysis of the key issues, and concerns for the future of the NIRP as a social protection policy. Specifically there is a need to adopt the best practices and lessons learnt from the STDP in future developments so that the NIRP is implemented and remains relevant to people affected by DIDR in Sri Lanka.

\section{CONCEPTUALISING DIDR}

Many people are displaced annually by development projects. However, the actual number often does not take into account certain categories of people such as those without legal title to land and people who live downstream and are displaced due to large dam projects. Further, unlike for refugees and internally displaced persons, there are no institutions or publications dedicated to tracking Development induced displacement and resettlement at either the global or the national level. As a result, there is a lack of precise data on the numbers of persons affected by development-induced displacement throughout the world (FMO, 2004).

The literature on development induced displacement and resettlement largely comprised of case studies. However, several theoretical frameworks have been proposed to explain the social consequences of forced relocation. Two models; the Scudder and Colson's four-stage model and Cernea's Impoverishment Risks and Reconstruction (IRR) model provide basic frameworks for anaylsing the varying levels of risks that might exist for a particular segment of a displaced population, and for comparing and contrasting the experiences of affected persons (FMO, 2004).

In the early 1980s, building upon earlier approaches that dealt primarily with the processes of voluntary resettlement, Scudder and Colson proposed a four-stage model of how people and socio-cultural systems respond to resettlement. The stages were labeled: recruitment, transition, potential development, and handing over or incorporation. The Scudder-Colson model focused on the different behavioural tendencies common to each of a series of stages through which re-settlers passed. At first, the model was formulated to explain the stages of voluntary settlement and was only later applied to some cases of involuntary resettlement. In the $1980 \mathrm{~s}$ and 1990s, the mounting evidence of involuntary resettlement schemes that failed to pass through all four stages suggested that a new model was necessary to explain the consequences of involuntary relocation. In particular, it was recognised that a new theory was necessary to model what was increasingly seen as predictable impoverishment (FMO, 2004).

Cernea's impoverishment risks and reconstruction model was formulated in the 1990s in response to this recognition. The IRR aims to identify the impoverishment risks intrinsic to forced resettlement and the processes necessary for reconstructing the livelihoods of affected persons. In particular, it stresses that unless specifically addressed by targeted policies, forced displacement can cause impoverishment among affected persons by bringing about landlessness, joblessness, homelessness, marginalisation, food insecurity, loss of access to common property resources, increased morbidity and mortality and community disarticulation. To these risks, Downing, (FMO, 2004) and others have added; loss of access to public services, disruption of formal education activities, and loss of civil and human rights. The model also recognises risks to the host population which, while not identical to those of displacees, can also result in impoverishment. Apart from identifying risks, the IRR model also predicts impoverishment, guides formulation of research hypotheses and the conduct of theory-led field investigations research. It also acts as a compass for risk reversal and advocates targeted resettlement policies such as land-based resettlement, job creation, health and nutritional safeguards, and social network rebuilding. 
Whilst the IRR model has been used as a framework for a number of studies, its limitations have been discussed. De Wet (FMO, 2004), points the importance of recognising the complexities inherent in the resettlement process, such as "non-rational" political motivations and difficulties with financing and institutional caffected personacity. Whilst he recognises the thoroughness of the IRR model, he concludes that the assumption, that resettlement problems can be erased by improvements in planning is overly optimistic (FMO, 2004).

Development induced displacement and resettlement also raises critical ethical issues; can development projects justify displacement? if so, under what conditions? Is it ethically acceptable to displace people on payment of monetary compensation? What type of compensation is owed to affected persons and when, if ever, is it deemed 'adequate'? Should affected persons share the benefits from the project by which they were displaced? Development induced displacement and resettlement is often justified under three broad ethical perspectives; public interest, self determination and egalitarianism (FMO, 2004). The public interest perspective supports the eminent domain principle, where a project is justified if there is greatest net benefit for the population as a whole. Displacement and potential impoverishment of some are treated as costs that can be outweighed by benefits to others. The self-determination perspective rests on the premise that forced displacement is unjust because it violates property rights. The egalitarian perspective privileges actions that reduce poverty and/or inequality. Theoretically, Development induced displacement and resettlement can be justified here if it benefits the wider community, but questions are raised when a project benefits some and impoverishes others, usually those who are already at the lower end of the economic ladder. Whilst compensation can be provided, the egalitarian perspective requires those displaced to be the recipients of the benefits of the project. As Penz (FMO, 2004) points out, Development induced displacement and resettlement is an ethically complex issue, in which public interest and distributive justice stand in tension with self-determination and individual rights. He concludes that conditions exist under which Development induced displacement and resettlement can be justified. They include the avoidance of coercive displacement in favour of negotiated settlement, the minimisation of resettlement numbers, the full compensation to Affected persons for all losses and the use of development benefits to reduce poverty and inequality (FMO, 2004).

Post colonial development policies and planning in South Asia have generally been based on the utilitarian Benthamite concept of 'greatest happiness for the greatest numbers (FMO, 2004). The concept of eminent domain can be described as the power that the state can exercise over land within its territory. In Development induced displacement and resettlement, the state exercises its right to appropriate private property for public use by evoking the concept of eminent domain. In Sri Lanka, eminent domain is exercised by evoking the Land Acquisition Act, legitimising the compulsory acquisition of land for development purposes in the national interest. Entitlements under eminent domain in the strictest sense apply only to private lands for those affected persons who have formal title to land. Communal property rights are not recognised under eminent domain. In practice what this means is that affected persons who have no formal land titles and enjoy access to common property resources are not entitled to land-for-land or cash compensation payments. As a result, when eminent domain is evoked, affected persons run the risk of becoming landless and consequently impoverished.

Mathur and Cernea (1994) states that, while the benefits from development projects accrue to society at large, the costs remain unequally shared. Those who bear the costs may not be those who enjoy the benefits and some may bear greater costs than others. As such, the application of the eminent domain principle has profound effects. Preference for use of property for 'public purpose' over individual interest can result in the impoverishment of entire communities. Although Development induced displacement and resettlement strategies have been formulated on the basis of Micheal Cernea's model which provides for full payment at replacement cost for assets lost with the intention that such payment will restore assets and incomes lost, families have found it increasingly difficult to buy land with the compensation paid and to make the shift from land-based to non landbased occupations. Grabska and Mehta (2008) states that a comparison of post resettlement experiences with those of pre-displacement indicates that on many occasions, affected persons have been negatively impacted resulting in impoverishment.

Guidelines and policies used for implementing Development induced displacement and resettlement projects have been influenced by Micheal Cernea's IRR for resettling affected persons. These guidelines and policy principles drew on Cernea's conceptual approach to measure and practically respond to Development induced displacement and resettlement. Using the model, planners and policymakers were able to identify an assortment of risks which accompany resettlement including landlessness, joblessness, homelessness, social marginalisation, increased mortality and morbidity, food insecurity, loss of access to common property and social 
disarticulation to anticipate and mitigate impoverishment (Cernea, 1997). The model also helped planners and policymakers understand what was involved in the impoverishment process so as to make resettlement planning and management more effective and contribute to re-establishing the displaced adequately. The central message from this model was that by estimating and ultimately reversing poverty-inducing risks associated with Development induced displacement and resettlement, impoverishment from displacement was preventable and not inevitable (Muggah, 2008).

Whilst development can be seen as a right to which all people should have access, people should also have the right to be protected from development's negative impacts including the loss of economic, social and political rights and arbitrary eviction. The goal of development should then be to improve livelihoods and the lives of all in a transparent and participatory process (Oliver-Smith, 2001 in Robinson, 2002).

\section{A BRIEF HISTORICAL OVERVIEW OF DIDR IN SRI LANKA}

Large-scale development initiatives which cause massive population displacement are not a new phenomenon in South Asia. In Sri Lanka, pockets of the population have been relocated from colonial times due to large-scale projects that sought to extend and diversify agricultural production. In the post independence period, large dam projects were championed for the multiple benefits they would provide: water for the growing urban population, irrigated agriculture for the rural communities and hydroelectric power for all. However, in practice, such projects have often come at an enormous social cost. State plans for large-scale development involve acquisition of private lands, homes and common property with detrimental consequences for those affected.

DIDR in Sri Lanka has mainly occurred due to irrigation development schemes causing displacement and consequent resettlement of affected persons in newly opened up areas for agricultural development (Kuruppu and Ganepola, 2005). The Accelerated Mahaweli Development Project (AMDP) implemented from the late 1970 s affected nearly 12,000 families, many of whom were displaced due to the submergence of their traditional lands in the highlands to rising waters from the river Mahaweli. Most of the affected families were resettled in new lands in the dry zone where the ecological system was different to the lands they had cultivated prior to displacement. In addition to coping with the difficulties of physical relocation, families had to learn to crop new varieties of grain in an unfamiliar terrain. In the months following resettlement, many affected persons suffered from health and nutritional problems including malnutrition and malaria.

In these early projects, land was acquired under the Land Acquisition Act (LAA) of 1950 (and subsequent amendments). The Act establishes the procedure to be followed for the acquisition of land for public purpose including the issue of notice of intended acquisition and notice of acquisition of land or servitude for a public purpose. Further provisions concern assessment and payment of compensation. State agencies which executed DIDR projects used the land acquisition act to acquire land. In many instances, land was acquired under section 38 (a) of the land acquisition act which enabled the immediate acquisition of land after issue of a public notice. These agencies paid a percentage of the compensation as interest from the date of execution of the law to the date of payment of compensation. They drew up their own individual Resettlement and Rehabilitation ( $\mathrm{R}$ \& R) entitlements and benefits matrix broadly following the principles embedded in the Cernea model but lacking detailed Resettlement Action or Implementation Plans (Land Acquisition Act no.8 1950). Numbers of those to be displaced and costs of resettlement were arbitrary with affected persons receiving varying levels of benefits. Compensation was paid only to those who lost their lands, houses or immovable property. On many occasions the quantum of compensation paid was insufficient. Further, compensation payments were often delayed and paid in installments causing enormous hardship to the displaced (ADB, 2001).

The Southern transport development project is the first controlled expressway to be constructed by the Government of Sri Lanka with the Road Development Authority as the implementing agency. The $128 \mathrm{~km}$ expressway from Kottawa in the Western Province to Matara in the Southern Province is also the first largescale development project which attempts to implement a DIDR project adopting the principles of the NIRP. It was thus, in many ways a 'learning' project for the Road Development Authority in particular, and for large scale development projects in Sri Lanka in general. A deeper analysis of the adoption of the NIRP in the Southern transport development project will follow in the section titled; the NIRP in practice.

\section{SOCIAL PROTECTION AND THE PRINCIPLES OF THE NIRP}

\section{Social protection as a concept}

Social protection as a concept is of fairly recent origin, often referring to public actions taken in response to levels of vulnerability, risk and deprivation which are deemed 
socially unacceptable. As such, protection measures are taken to ensure that vulnerable populations, particularly the poor, effectively reduce their exposure to risks and improve their prospects for human capital development.

The literature (ODI, 2001) states that social protection policy is closely connected to debates on social cohesion and social exclusion. This is a social sciences perspective of social protection which sees social life as defined by collective inclusion, providing mutual assistance and basic material needs while fostering inclusion of recipients in mainstream society. It reflects social protection as a field of policy and action which does not stand alone but overlaps with other programmatic approaches in delivering assistance to the poorest, strengthening livelihoods and reducing vulnerabilities. However, a broader definition of the term emphasises the importance of protecting all those who fall temporarily or persistently under levels of income and or consumption which are deemed acceptable (ODI, 2001). Social protection programmes often target vulnerable population groups and gender issues, dealing with absolute deprivation and vulnerabilities of the poorest. Programmes and interventions also provide economic and social 'cushioning' for non poor in times of shocks such as natural disasters. The 'public' character of this response may be governmental or non-governmental, or may involve a combination of institutions from both sectors (Norton, Conway \& Foster, 2001).

In Sri Lanka whilst social welfare and assistance to vulnerable groups is carried out at policy and programme level, 'social protection' as a term is less used, terms such as social 'safety net' and 'social security' are more often used in the social protection discourse in Sri Lanka (ADB, 2001). Social protection policy has evolved from the need to provide minimum acceptable standards for maintaining livelihoods and for protecting lives and livelihoods from the risk of adverse impacts when faced with economic shocks or natural disasters.

As mentioned earlier, development-induced displacement is not a new phenomenon in Sri Lanka. Until 2001, there were no national level policies or general guidelines on involuntary resettlement. Land was often acquired under the Land Acquisition Act within the concept of eminent domain. The Act dealt with the legal process of land expropriation and financial compensation payment with no specific mechanism to deal with resettlement in ways that would prevent impoverishment and reduce vulnerability. However, there was growing recognition, specifically within civil society and the donor community, that aspects of social protection need to be converted into entitlements when private land is acquired for development projects. It is within this context that the NIRP was formulated.

\section{The Principles of the NIRP}

The NIRP was formulated in 2000 with substantial support from international funding agencies such as the Asian Development Bank, and approved by Cabinet in 2001. Described as the first such policy in South Asia, the NIRP provides principles, rules and norms to protect displaced populations, to ensure a fair, equitable and transparent DIDR process. The policy requires implementing agencies to submit detailed Resettlement Implementing Plans, for all projects displacing twenty or more people and requires project authorities to pay compensation for land at replacement value. Critically, the policy states that impoverishment should not take place as a result of compulsory land acquisition. The policy principles state that vulnerable groups must be identified and provided assistance to improve their living standards (NIRP, 2001). The policy is considered a 'soft law' serving as a normative tool to address gaps in existing legislation (Muggah, 2008). It is therefore not legally admissible in a court of law at the present time. Policy principles include:

- Involuntary resettlement should be avoided or reduced by reviewing alternative project options.

- Where unavoidable, project affected persons should be assisted to re-establish and improve the quality of life.

- Resettlement should be planned as a development activity for affected person's.

- Selection of resettlement sites, livelihood compensation and development options should be explored with the participation of the affected persons.

- In the event of loss of land, replacement land should be an option for compensation. If replacement land is not available, cash compensation should be an option.

- Compensation for fixed structures, other assets and income including transaction costs, should be based on full replacement cost which should be paid promptly.

- Provincialandlocalauthoritiesshouldfullyparticipate in resettlement planning and implementation.

- Participatory measures should be designed and implemented to assist affected persons to economically and socially integrate with host communities. 
- Common property resources, community and public services should be provided to affected persons.

- Affected persons who do not have documented title to land should be treated fairly and justly.

- Gender equity and equality should be adhered to in the implementation of the policy.

- Vulnerable groups should be identified and given assistance to improve their living standards.

- $\quad$ Project executing agencies should bear the full cost of compensation and resettlement.

The policy provides specific institutional responsibilities to the Ministry of Lands and the Central Environmental Authority which are;

Ministry of Lands: Implementation of the policy, preparing guidelines and regulations on involuntary resettlement planning, implementation and monitoring, drafting amendments to the land acquisition act to bring it in line with the NIRP, submission of a final draft to amend the land acquisition act for government approval, preparation of required implementation guidelines based on the amended land acquisition act, and together with the Central Environment Authority, conduct training on resettlement planning, implementation and monitoring.

Central Environmental Authority: Responsible for assessment of and mitigating impacts of involuntary resettlement, providing guidance to agencies undertaking projects with involuntary resettlement, review and approve resettlement action plans prepared by Project Executing Agencies (PEA) and make those plans publicly available, and together with the Ministry of Lands (MOL) conduct training on resettlement planning, implementation and monitoring.

Project ExecutingAgency(PEA): Primary responsibility for planning and implementing resettlement is with the PEA. In a situation where the PEA has a project with significant resettlement, a resettlement unit with trained staff should be established within the PEA (NIRP, 2001).

The NIRP provides a 'cushion' from economic and social vulnerability by its key principle that involuntary resettlement should be carried out only if it is unavoidable. The land-for-land option for lost land or cash compensation in lieu of land at 'replacement value' restores affected persons access to land. Prompt compensation payments for livelihood restoration, effectively provides a source of income in the transition period between displacement and replacement or until affected persons are able to restart productive economic activity. The social 'cushioning' provides for integration of host and resettled communities and access to common property resources such as places of religious worship, community and public services.

The policy recognises the potential disruptive effects of displacement and resettlement, depriving communities of property and livelihoods, weakening or destroying the fabric on which communities are built and sustained, creating vulnerability and specific needs, a place to live, money to exist, livelihoods for economic sustainability and access to basic facilities in health, education, community and public services. Thus the policy recognises that affected persons are likely to suffer both economic and social vulnerabilities in the course of displacement and resettlement and provides measures to ensure that those vulnerabilities are mitigated.

\section{RESEARCH METHODOLOGY}

In this section the implementation of the NIRP will be analysed using a case study approach. Due to availability of data, the Southern transport development project will be the focus of this analysis.

\section{Research Hypothesis and questions}

The research hypothesis is; the assistance given through the project helped the affected persons to restore and improve their lives and livelihoods.

In line with the above research hypothesis, three research questions were identified based on three key NIRP principles. They are:

- Was resettlement planned as a development activity?

- Were the affected persons assisted to re-establish and improve their quality of life?

- Were affected persons provided the opportunity to participate in the resettlement process?

\section{Data collection}

The Centre for Poverty Analysis (CEPA) was appointed as the External Monitor for Resettlement by the Asian Development Bank in 2006 for a technical assistance project titled 'Monitoring of resettlement activities in the Southern Transport Development Project'. Resettlement activities were carried out by the Road Development Authority (RDA) as the project executor and CEPA's role was to monitor both the processes carried out and the experiences of the affected persons during the displacement and subsequent resettlement. CEPA 
conducted resettlement monitoring in six phases from 2006 to 2011 . The findings shared in this paper are largely from the data collected from this assignment.

Data was collected from 400 households in all 32 resettlement sites which were developed by the Road Development Authority for affected persons. In addition, Key Person Interviews (KPIs) were held with central and regional level officials of the Road Development Authority and other officials involved in land acquisition and resettlement activities such as Divisional Secretaries, Government Valuers and officials from the Survey Department.

The household data collection used a mixed, qualitative and quantitative data collection methodology to collect data on issues such as land acquisition process, payment of compensations, impact of displacement on the household, replacement of lost assets, restoration of lives and livelihoods. The household data collection sought information both to verify the processes carried out by the project executing agencies and to understand the impacts of the displacement and resettlement on the households.

\section{DATA ANALYSIS - NIRP IN PRACTICE}

This section will consist of an analysis of current development projects in which the principles of the NIRP have been implemented. Due to the availability of data, the STDP will be the primary case study used for the purpose of illustrating evidence of the facts. In line with the research questions, this analysis will be done under the following NIRP Principles.

\section{Principle 1: Resettlement should be planned as a development activity}

This principle envisages DIDR as a development process from which affected persons can benefit. Planning therefore is a key activity in implementing this principle.

\section{Resettlement as a development activity}

The resettlement implementing plan in the Southern transport development project identified ways that affected persons could benefit from the expressway and made provisions in the entitlement matrix to reflect this. For example, affected persons who lost commercial properties such as shops were prioritised for allocation of land plots at the interchange sites. It was expected that with the increased traffic on the expressway, opportunities to increase income generation would improve and that preferential access to prime commercial land plots would provide an opportunity for affected persons to benefit from the expressway.

In the STDP, affected persons who did have legal titles to land were recognised as being eligible to a right to compensation. The NIRP states that 'affected persons who do not have documented title to land should be treated fairly and justly' (NIRP, 2001). The STDP was the first development project which explicitly adopted this principle which was intended to recognise those who use land without legal title. The longer term objective of adopting this principle was to turn affected persons who did not have legal title to land into project beneficiaries. In addition to title holders and other regularised encroachers, the resettlement implementing plan recognises the right to compensation of non-title holders such as tenants and unregularised encroachers on private lands. Compensation to them has been paid in the form of Land Development payment (Sanwardhena Aithiya) based on the value of produce or structures and improvements on the land. Through the project intervention, these nontitle holders had not only become home owners but had significantly better housing facilities through permanent structures with pipe-borne water and electricity. These non-title holders had moved from a wattle and daub house or a plank house to permanent brick/cement block housing (CEPA, 2007). This category of affected persons was one of the most satisfied, because they had improved the quality of their lives as a result of the STDP adopting a key principle of the NIRP. As one new homeowner remarked;

'We were tenants at -----'s house and we lived
there for 10 years. We paid Rs. 100 monthly as
the rent. We did not have money to buy a piece
of land. We didn't have any land before, now we
have 30p land of our own which we bought from
the compensation paid by the Southern transport
development project' (CEPA, 2007).

Affected persons in the Upper Kotmale Hydro Power Project (UKHPP) ${ }^{1}$ are reported to have expressed satisfaction with the quality of housing units provided (Government News Portal, 2010). Many of the affected persons had previously lived in tin-roofed line rooms which had a verandah, a room and shared kitchen and bathroom facilities with other families. Under the project all affected persons were allocated housing units with separate kitchen and bathroom facilities with pipe-borne water and electricity facilities, fitted pantry cupboards, ceiling fans and lamp shades. For those who earned a

1 The Kotmale Hydro Power Project is a hydro power plant and a large dam to create a reservoir in the Kotmale valley. 
livelihood through cultivating produce in home gardens plots of land were allocated to grow fruits, vegetables and flowers for commercial purposes (Government News Portal, 2010).

The Lunawe Environmental Improvement and Community Development Project (LEICDP) $)^{2}$ also reports of affected persons being beneficiaries of the development project. Located in a high density urban environment, the project aimed to mitigate poverty by conferring land tenure rights to the poor living in underserved settlements. Further, as compensation, payments were paid to bank accounts, those affected persons who were not part of the formal economy were provided an opportunity to open bank accounts and access credit and savings facilities (LEIDP, 2010).

\section{Principle 2: Affected Persons (APs) should be assisted to re-establish and improve the quality of life}

The interpretation of the NIRP principle in relation to 're-establishing and improving the quality of life of the affected persons' (NIRP, 2001) consists both of the economic and social aspects of the affected person life with the intention of restoring, at the very minimum, the economic and social standards of the affected persons.

The STDP resettlement implementing plan was designed to restore, at the minimum, living and livelihoods standards of affected persons to pre-project levels. The resettlement implementing plan targets were to:

- Replace lost fixed assets,

- Restore living standards,

- Restore livelihoods,

- Restore social networks and common property resources.

For the purpose of this paper the first three points are analysed in terms of economic assistance and the last one in terms of social assistance.

\section{Economic assistance}

\section{Compensation at replacement value: replacing fixed assets}

Prior to NIRP the compensation package for a development induced displacement and resettlement project was based on a government valuation which was often less than the market value of the lost asset. The NIRP principle is based on the realisation that assets lost should be compensated at replacement value so that affected persons are not less better off as a result of development induced displacement and resettlement and are able at the very minimum, to purchase assets of a comparable nature and value. The STDP was one of the first development induced displacement and resettlement projects to pay compensation at replacement value over the government standard compensation paid under the Land Acquisition Act. Assets which fell under this category included both housing and land.

Housing: Economic assistance in the STDP was based on the recognition that compensation at replacement value is the first step to economic recovery of affected persons. The Southern transport development project adopted a key principle of the NIRP to offer land-for-land or monetary compensation in lieu of land. Accordingly, housing has been a priority for 'replacement'. The project provided affected persons with two options; a plot of land in a resettlement site plus monetary compensation, or monetary compensation only for self relocation. Those who chose the resettlement site option were usually provided a house plot and built their houses with the compensation paid. Many affected persons selected this option and moved from an essentially rural environment to one with more urban features; small plots of land in close proximity to each other with utility facilities such as pipe borne water and electricity. Those who chose the self relocation option were able to purchase land and build houses at sites of their choice with the compensation paid. The Independent External Monitor (IEM) revealed that $84 \%$ of households surveyed had moved to permanent housing, with the majority of householders implying satisfaction with their current housing conditions (CEPA, 2007).

Land: The project adopted a similar strategy with replacement of land for agriculture or non-agriculture purposes. Whilst the first choice was to offer land, the limited availability of suitable land made it difficult to offer the land-for-land option as has been noted in the replacement of paddy lands which will be discussed later in this section (CEPA, 2007).

However, in the STDP not all affected persons have benefited from economic assistance through the principle of 'replacement value'. In practice, many affected persons have not been able to 'replace' assets lost due to a time lag from the time the properties were valued to payment of final compensation and due to delays caused by payment of compensation in tranches. The land acquisition procedure involves multiple institutions such as the Survey Department, Valuation Department and the Divisional Secretariat, sometimes resulting in several years between valuation and final compensation payment. As revealed through the independent external monitor of resettlement, the time period between the property being valued and payment of final compensation in some

2 LEICDP aimed to mitigate flood damage by improving urban drainage and the canal system which resulted in many families living on the canal banks being resettled. 
instances consisted of three years during which time land prices had increased substantially. As a consequence, affected persons were unable to purchase new properties of comparable form and value as those lost. Further, with the increasing population density in certain geographical areas of Sri Lanka including the Western and Southern Provinces, the availability of land is fast diminishing. This is particularly true for paddy lands. The independent external monitor of resettlement revealed that farmers who had lost paddy lands as a result of the Southern transport development project had found it increasingly difficult to replace paddy lands (CEPA, 2007). Further, the practice of paying compensation in instalments, usually three instalments within a stipulated time, during the project period and the escalation of property values and prices over the ensuing time period has resulted in difficulties in purchasing and replacing properties.

\section{Restoring living standards}

Relocation allowances: The Southern transport development project recognised that relocation was a difficult transition period from displacement through resettlement. Cash allowances were made aiming to facilitate financial losses incurred, including reimbursement for relocation of electricity and water facilities, temporary house rent allowance, resettlement allowance, shifting allowance and documentation allowance towards the transaction cost of arranging legal documentation to aid land acquisition and compensation. To facilitate and encourage speedier vacation of properties, an incentive was provided which was a $25 \%$ lump sum payment of the value of land and structures when the property was vacated before or on the stipulated date (Road Development Authority, 2002).

Living environment: There was much less effort expended to recreate the living environment of the affected persons. This was partly due to difficulties which arose as a result of the restricted space in the new environment. Those affected persons who chose the resettlement ${ }^{3}$ site option were given plots of land in close proximity to each other, usually no more than twenty perches on which the house was constructed with a small home garden. This living environment was physically different from the one they had vacated which was essentially rural with large open spaces and fluid boundaries between neighbours. Whilst the Resettlement implementing plan in the Southern transport development project prioritised physical relocation in terms of housing and other fixed structures, replacement of the natural environment received far less attention. The IEM revealed that many affected persons were dissatisfied with the new living environment which was articulated in terms of loss of the rural environment; the space, the shade of the trees, the freedom to move over larger spaces, accessibility and availability of fruits and vegetables, organic garbage disposal and natural water drainage systems. In particular, they lamented the loss of ancestral family burial plots and common property resources for animal grazing and collection of fire wood. Thus, affected persons felt they lost their ability to connect with nature (CEPA, 2007).. As one affected person commented,

\section{'There are no trees here. We cannot grow anything here without bringing in new soil because the ground is full of stones. A vehicle cannot even come to the house because the tyres sink in to the mud and a dozer is needed to remove the vehicle. The water from the road comes to the house.' (CEPA, 2007)}

In contrast, the Lunawe environmental improvement and community development project reports paying particular attention to providing a pleasant and environmentally sustainable urban living environment. The project provided an improved solid waste management system and constructed storm water drainage systems and rehabilitated canals and streams (LEI, 2010). Whilst the STDP also provided such amenities the higher satisfaction levels in the Lunawe environmental improvement and community development project could be attributed to the fact that the relocation in the LEICDP was essentially an urban-urban one, whereas, in the STDP it was, in some instances, such as in the resettlement sites, a ruralurban transformation to which the affected persons had not yet fully adjusted.

\section{Restoring Livelihoods}

The NIRP principle of 'Affected persons should be assisted to re-establish and improve the quality of life' (NIRP, 2001) by implication suggests that affected persons should be assisted to restore their livelihood sources at the resettled location.

In principle the resettlement implementing plan of the STDP provided both monetary and non-monetary assistance to restore livelihoods. The monetary compensation included value of commercial land lost and cash allowances towards loss of income to address issues concerned with loss of livelihood and employment. The non-monetary component addressed restoring and improving livelihood sources through access to training and advisory services.

${ }^{3}$ Sites developed by RDA where APs were provided with a 20 perch block of land at a nominal fee 
Loss of livelihood and employment: In the Southern transport development project, whilst restoration of housing facilities was given priority, the Income restoration programme received less attention. As stated earlier, the IEM found that replacement of agricultural land was low, particularly for paddy land owners, with $90 \%$ of paddy land owners not replacing their paddy lands. Similarly, small land owners of tea, rubber and other cash crops had also found it difficult to replace these lands, resulting in difficulties in restoring livelihoods to pre-project levels (Kumarasiri, 2009).

In the same way, affected persons who lost commercial properties also found it difficult to restore livelihoods to pre-project levels, with $45 \%$ indicating that they had not been able to restore commercial livelihood activities (Kumarasiri, 2009). Restoring livelihoods in commercial activities was difficult due to several factors; some were affected due to the fact that the current location was in a non -commercial area. This was particularly so for those owning and running shops, whilst others were not able to re-start commercial activities due to the breakdown of existing networks such as availability of raw material and disruption of marketing links. As one affected person remarked:

\section{'We lost a lot because of land acquisition. Before I could use my parents' land to rear my animals. There I had cows and goats and that brought me additional income. There I used to sell coconut charcoal (polkatu anguru) and here I cannot do it because if I start burning coconut shells people might chase me away. It needs a lot of space and I had it in the earlier place. We used to sell coconut spoons, then people came to our house to buy coconut spoons. There were people who came to buy vegetables from our vegetable patch (kotuwa) as well. But now we have to go from place to place to sell them.' (CEPA, 2007)}

In some instances the STDP also provided assistance for agriculture and commercial properties where livelihoods were disrupted due to loss of property. An allowance was made for loss of business, paid to affected entrepreneurs as well as workers and sharecroppers employed in such livelihood activities who were likely to be affected by loss of employment which resulted in affecting livelihoods (Resettlement implementing plan for STDP 2002). This included special dispensation for vulnerable affected persons such as female headed households, the disabled, the elderly and those whose economic circumstances were below the accepted minimum such as Samurdhi welfare beneficiaries. These allowances were made on a case-by-case basis.

Many affected persons in the Colombo Kandy Highway engaged in subsistence farming and fisheries activities, expressed concerns about the threat to food security due to relocation which would disrupt food sources and result in the need to purchase food for consumption (Kuruppu and Ganepola, 2005). The above study undertaken in 2005 revealed that in both the Southern Transport Development Project and the Colombo Katunayake Expressway, the impacts of relocation on livelihoods was significant with disruption of income sources having far reaching consequences for poverty and the creation of impoverishment in areas which previously did not have poverty.

The Southern transport development project also provided non-monetary assistance to find land and income restoration programmes, to help with restoring livelihood activities. The income restoration programme provided access to training programmes for both agriculture and non-agriculture based skills training, provided house plants, opportunities to learn about new agricultural techniques and move from subsistence to commercial farming methods. Further, this component included access to services such as individual consultations and advice on livelihood restoration (Road Development Authority,2002).

In the Lunawe environmental improvement and community development project the Non-governmental Organization (NGO) partner provided information on construction practices such as housing designs, and low cost building techniques, advisory services such as obtaining approvals from local authorities and skill training on supervising house construction (LEICDP, 2010).

\section{Social assistance: Restoring common property resources and social and kinship ties}

The NIRP principle that 'affected persons should be assisted to re-establish and improve the quality of life' is a recognition, that affected persons have made a personal sacrifice in the national interest for the benefit of the larger community. It thus, confers a responsibility on the part of the agency causing displacement to acknowledge that sacrifice, and take actions to mitigate its negative impacts. This includes the disruption of social networks and loss of common property resources such as grazing lands, schools, places of religious worship, burial grounds, community centers and other community facilities and services.

The resettlement implementing plan in the STDP identifies common property resources as a separate category in the land acquisition process. As such, structures, services and spaces of common usage such as schools, health units, places of religious worship and markets, community infrastructure services such as roads and waterways and common spaces such as 
forests and grazing areas fall within this category. Whilst replacement land or cash in lieu of land, forms the basis of compensation for private land, replacement of facilities and services form the basis of restoring common property resources.

The resettlement implementing plan requires these common resources to be replaced at previous or improved levels. While cash compensation is an entitlement for fixed structures, replacement of common facilities and services are prioritised in consultation with the user community and replacement of the facility prior to the commencement of the project are required as per the Resettlement implementing plan. Despite these requirements, the IEM revealed that affected persons often face hardships as access roads, drainage systems and canals and other common resources are disrupted. As an affected person remarked;

'Yes we can use the underpass. It's a metal arch, therefore the road is gloomy like a tunnel. It is difficult go to the other side at dusk and at night, there are men hanging around and no one can see as it's no longer open like the road. ' (CEPA, 2007)

Displacement and resettlement often result in breakdown of social and cultural networks potentially exacerbating personal and economic vulnerability. Moreover, the loss or disruption of social bonds through displacement is likely to lead to the disruption of communal mechanisms that help to ensure the protection of the most vulnerable - especially those outside conventional family structures or responsible for heading households. A recurrent theme in DIDR is the disruption of social and kinship ties. When a community is relocated it is reconfigured, restructuring social, economic and political relationships often resulting in the fragmentation of the community. In the STDP, the dismantling of communal production through joint paddy cultivation, severance of generational residential communities and informal social networks caused social disintegration (Kuruppu \& Ganepola, 2005). For women in particular, the effects of DIDR are particularly traumatic due to its impact on the quality of life threatened by disruption of family kinship. Many displaced people, particularly women, prefer to move together with the rest of the community, neighbourhood or kin group.

In the STDP, affected person families had the choice of moving to resettlement sites where the neighbourhood structures could be maintained. This was possible by exercising the option to move to a resettlement site as a community, in close proximity with their neighbours to ensure minimum disruption of community ties. Housing societies were set up to help communities adjust to new surroundings. However, a study (Kuruppu \& Ganepola, 2005) conducted on the STDP, revealed that women often complained of loss of support systems such as neighbours and villagers and the participation in community traditions such as Shramadana. Similarly in the Colombo Katunayake Expressway, affected persons felt that they stood to lose their way of life, their connection with the village and neighbours. Their sense of belonging extended beyond their individual self and personal properties to communal structures, access to communal property resources and the micro culture of the village they were leaving behind (Kuruppu \& Ganepola, 2005).

The LEICDP provided a community development programme as a sub-component of the project to include both affected persons and host families at the resettlement sites. The project carried out host community impact assessment and introduced activities to address impacts and to enhance the quality of life of the host communities to match the standards of the re-settlers. Further, it reportedly strengthened linkages between Community Based Organisations (CBOs) in the resettlement sites and upgraded settlement and other institutions (Lunawe environmental improvement and community development project, 2010).

Principle 3: All stages of the resettlement process should be implemented with the participation of the affected persons: Disclosure and consultation with stakeholders

This principle was based on the recognition that development induced displacement and resettlement is a complex process involving many stakeholders with different interests in the project planning and implementation stages. The principle aimed to ensure that resettlement planning and implementation is an inclusive process ensuring the participation and consultation of all major stakeholders, essentially the affected persons, the implementing agency and local authorities. The principle enshrines broad measures to make resettlement more equitable through factors such as providing an element of choice in selection of resettlement sites and access to a grievance redress mechanism.

The STDP encouraged affected person participation in resettlement planning and implementation through the establishment of the Land Acquisition and Resettlement Committee (LARC) and the Grievance Redress Committee (GRC). The Land Acquisition and Reclamation Committee provides an opportunity for affected persons to negotiate replacement value for land and is also a forum for affected persons to understand, participate and be consulted on the process 
of land acquisition and compensation. In particular, Land Acquisition and Reclamation Committee meetings provided affected persons an opportunity to influence and negotiate a replacement cost for their fixed assets. Land Acquisition and Reclamation Committee meetings are convened at the Divisional Secretariat office and provides a platform for discussions between the affected persons and their representative the implementing agency i.e. the Resettlement Officer from the Road Development Authority, local officials i.e. Divisional Secretary and representatives of key public officials such as the Chief Valuer and Surveyor General's office. Further, the fact that meetings were held locally at the Divisional Secretariat made the Committee accessible to all affected persons. When the need for an appeal against a Land Acquisition and Reclamation Committee decision was deemed necessary, a Super Land Acquisition and Reclamation Committee was established at the ministerial level. The Super Land Acquisition and Reclamation Committee provided affected persons the opportunity of interacting with officials of the highest level. It accommodated compensation related grievances for which a Land Acquisition and Reclamation Committee solution was not satisfactory. This consultative process is an important and significant mechanism used by the STDP to embrace the NIRP principle of encouraging stakeholders to participate in resettlement planning and implementation. This process has worked effectively, as reflected in a comment made by an affected person:

'It is a very good concept. If it had not been there we would have had no place to talk. (Antha Asaranai) Here we could negotiate to increase it. It was really good when we compare to what happened in the Mahaweli Project' (CEPA, 2007).

While Land Acquisition and Reclamation Committee essentially addresses compensation related issues, the aim of the Grievance Redress Committee, as stated in the Resettlement implementing plan, is to address noncompensation related grievances. Accordingly Grievance Redress Committees have been set up in each district to ensure that project related complaints are being addressed on an ongoing basis. However, as revealed in the IEM, few affected persons are aware of this mechanism and fewer still have used it to air their grievances resulting in the Land Acquisition and Reclamation Committee, by default being the primary mechanism used to address all grievances. As a result of the under-utilisation of district level Grievance Redress Committees, a new revised version was implemented at the DS level with greater success, handling more than 500 cases between 2006 and 2008 (CEPA, 2009).
The Colombo Katunayake Expressway provided opportunities for greater engagement with affected persons at the onset which gradually decreased over time. This project had fewer incidences of protests than the STDP which has been attributed to a lack of transparency and availability of public information on the project which precluded affected persons being organised into groups to protest. In comparison to the STDP, affected persons in Colombo Katunayake Expressway seemed more resigned to the project with few affected persons stating that they had been involved in active protests against the project in general (Kuruppu \& Ganepola, 2005).

The LEICDP reports being successful in involving key stakeholders to participate in the decision making process. Considerable time and effort was expended at the planning stages to ensure 'inclusiveness'; and build an environment where trust and goodwill was created. As a result, protests against the project were minimal. Further, the project was sustained through strategic partnerships between key institutions; government institutions, the donor, the implementing agency and non-governmental organization to act as an intermediary to market the project to affected persons. The nongovernmental organization conducted several rounds of visits to prospective affected person households to keep affected persons informed of project objectives and plans and to reduce the spread of rumours and distrust between affected persons and project implementers. The project reports that this process contributed to greater transparency in the implementation process and helped maintain the number of objections to the minimum. A community information centre was established in the project office serving as a one-stop-shop for enquiries and complaints from affected persons. The project also created neighbourhood development forums to establish and maintain communication links between re-settlers, host communities and other stakeholders at the new sites (LEICDP, 2010). Further, an entitlement assessment committee was set up which afforded affected persons an opportunity to be briefed on the rationale for computing his/her entitlement package. It also provided a forum to clarify issues and entertain suggestions and comments and even reject proposed entitlements.

\section{CONCLUSION}

The NIRP as a 'protection' policy provides both economic and social measures to cushion affected persons from economic impoverishment and to restore their social wellbeing. As discussed, the economic protection measures help affected persons to recover their economic position so that they are able to resume their lives without having to bear financial difficulties. Land-for-land or 
cash compensation in lieu of land is the basis on which fixed assets are replaced. Further, the policy attempts to restore and minimise the impacts on livelihood activities so that income streams are maintained and affected persons are not negatively impacted by loss or disruption of income sources. Thus the NIRP enshrines measures to replace fixed assets, restore living standards, compensate for loss of livelihoods and provides allowances to tide over time frames until income generating activities can be resumed.

The social wellbeing measures are addressed by provisions to re-establish and improve the quality of life and to provide common property resources, community and public services to improve living conditions. These measures are a recognition that displacement and resettlement are economically and socially disruptive and those who are making a personal sacrifice for the greater good in the national interest should be assisted to re-establish their lives.

As a pre-requisite for meeting a loan covenant, the Southern transport development project adopted the principles of the NIRP. As analysed in this paper, the STDP made a concerted effort towards replacement of fixed assets through provision of housing in resettlement sites and compensation for self relocation and land-forland or cash in lieu of land for replacement of agriculture and non-agricultural lands. In terms of restoring living standards, monetary assistance was provided through cash allowances for transactional costs of relocation. However, creating the living environment received less attention. In restoring livelihood standards, the STDP success was limited due to the fact that many affected persons engaged in agriculture or non-agriculture landbased livelihoods. The lack of suitable land and the relocation, especially for those affected persons that chose the resettlement site option, from an essentially rural to an urban living environment meant that affected persons had to find new livelihood sources or had to adapt livelihoods to new surroundings. Whilst there was an intention to avoid impoverishment through the project this objective was not always fully translated into action in real time as attempts at restoring livelihoods were not as speedy or as effective to enable affected persons to restore their income streams.

In the STDP, the Land Acquisition and Reclamation Committee, Super Land Acquisition and Reclamation Committee and Grievance Redress Committee provided fora for interaction between the different stakeholders. However, many affected persons were experiencing emotional distress due to disruption or severance of social and kinship networks, loss of common property resources, especially family burial plots and loss of the rural environment. These losses are much harder to quantify and received much less attention by the project. Both the STDP and Lunawe environmental improvement and community development project are projects in which the donor influenced adoption of the NIRP principles. However, more recent slum clearance programmes in and around Colombo have been carried out without adopting the NIRP and therefore provides no social protection measures to affected persons. Further, the government is reported to have appersonproved a plan to evict sixty six thousand families in shanties in Colombo to make way for private development programmes. It is expected that this shanty and hawker clearance programme will be extended to other towns in the island as well (Sunday Leader, 2011).

To ensure that the NIRP is adopted and the principles are adhered to, immediate action is required. Firstly, a mechanism needs to be in place to ensure that the lessons learnt from the STDP are documented and readily available to agencies which carry out development induced displacement and resettlement projects. Secondly, the appointment of a 'Champion' to ensure that the principles of the NIRP are adopted by all agencies carrying out development induced displacement and resettlement is another step that needs to be taken. Although the NIRP policy document recommends the Ministry of Land as the most appropriate agency to be the guardian of the policy, the Ministry has been ineffective in carrying out this activity. In this context, what is suggested is that a committee be appointed consisting of representatives of relevant agencies such as the Central Environment Authority, Ministry of Lands, key implementing agencies such as the Road Development Authority and civil society members, and entrusted with the task of ensuring that the principles of the NIRP are adopted in all development induced displacement and resettlement projects. Further, sub committees with expertise in resettlement planning and implementation and in resettlement monitoring should be established to ensure that the NIRP remains relevant and applicable as a social protection policy, to address issues of involuntary displacement and resettlement.

\section{ACKNOWLEDGEMENT}

The author is grateful to the Asian Development Bank, Sri Lanka Mission (ADB) for giving the opportunity to use the data generated from the ADB funded TA4748 SRI. The Centre for Poverty Analysis (CEPA) was appointed by the Government of Sri Lanka and the ADB under the TA as the Independent External Monitor of the resettlement activities of the Southern Transport Development Project (STDP) and remained actively engaged with the STDP through this assignment. We are also grateful to officials of the Road Development 
Authority and other agencies connected with the STDP for their cooperation at all stages of this assignment.

\section{References}

1. Anver, G. \& Wickrematunge, R., 2011. Evicted. Sunday Leader. [online] Available at: $<\mathrm{http} / / \mathrm{www}$.thesundayleader. lk/2011/05/08/evicted/> [Accessed 20 October 2010].

2. Asian Development Bank, 2001. Sri Lanka: Developing a National Policy on Involuntary Resettlement, Interim Report, Manila: ADB.

3. Centre for Poverty Analysis, 2007. Independent External Monitoring of the Southern Transport Development Project, Final Report, Colombo:CEPA.

4. Centre for Poverty Analysis, 2009. A Review of the Southern Transport Development Project (STDP): Grievance Redress Mechanisms, Consolidate Final Report, Colombo:CEPA.

5. Cernea, M., 1997. Risks and Reconstruction Model for Resettling Displaced Populations. [online] Available at:<http://www.massey.ac.n3/ trauma/issues/2002-2/ mcdowell.htm $>$ [Accessed 11 May 2009].

6. Forced Migration Online, 2004. Development induced displacement and desettlement. [online] Available at: $<$ http://www.forcedmigration.org/guides/fmo022/> [Accessed 12 October 2010].

7. Gabska, K. \& Mehta, L. eds., 2008. Forced Displacement: Why Rights Matter. New York: McMillan.

8. Government News Portal, 2010. [online] Available at: $<\mathrm{http}: / /$ www.news.lk/> [Accessed 5 November 2010].

9. Kumarasiri, M., Southern Transport Development Project: Experiences and Lessons for Livelihood Restoration Assistance, in Fernando, P., (et al) ed., 2009. Forced to Move, Involuntary Displacement and Resettlement Policy and Practice, Colombo: CEPA.
10. Kuruppu, S. \& Ganepola, V., 2005. Whose Right of Way? In: CEPA Working Paper 10. Colombo:CEPA.

11. Mathur, H. M. \& Cernea, M. eds., 1994. Development, Displacement and Resettlement: Focus on Asian Experience. New Delhi: Oxford University Press.

12. Mathur, H.M. \& Marsden, D. eds., 1998. Development Projects and Impoverishment Risks: Resettling ProjectAffected People in India. New Delhi: Oxford University Press.

13. Muggah, R., 2008. Relocation Failures in Sri Lanka: A Short History of Internal Displacement, London: Zed Books.

14. National Involuntary Resettlement Policy, 2001. [online] Available at: <www.adb.org/resettlement/nirp_2001.pdf-> [Accessed 24 November 2010].

15. Norton, A., Conway, T. \& Foster, M., 2001. Social Protection Concepts and Approaches: Implications for Policy and Practice in International Development, Working Paper 143. [online] Available at: <http://www.gsdrc.org/ go/topic-guides/social-protection/understanding-socialprotection $>$ [Accessed 20 September 2010]

16. Oliver-Smith, A. \& Hansen, A. eds., 1982. Involuntary Migration and Resettlement: The Problems and Responses of Dislocated People. Boulder: West View Press.

17. Road Development Authority, 2002. Resettlement Implementation Plan for Southern Transport Development Project (STDP). Colombo unpublished.

18. Robinson, J., 2002. Development and Displacement. Milton Keynes: Open University Press in association with Oxford University Press. 